\title{
Lower Tithonian microconchiate simoceratins from eastern Mexico: Taxonomy, biostratigraphy, and paleobiogeography
}

Ana B. Villaseñor, Federico Olóriz, and Celestina González-Arreola Acta Palaeontologica Polonica 56 (1), 2011: 133-158 doi: http://dx.doi.org/10.4202/app.2010.0030

The precise record of simoceratins sampled bed-by-bed is first reported from Mexico (Mazatepec area in Puebla, central-eastern Mexico), as well as the existence of lappeted peristomes in these ammonites. Both Pseudovolanoceras aesinense and the subspecies Pseudovolanoceras aesinense chignahuapense are shown to occur among Mexican simoceratins. The European species and the Mexican subspecies share the same stratigraphic range in the studied sections, yet they differ in ephebic sculpture. Ecological adaptation to neritic seas corresponding to eastern Mexico areas isinterpreted, forcing phenotypic deviation with geographic significance, i.e., subspeciation. The new subspecies would indicate stratigraphic horizons within the Semiformiceras semiforme/Haploceras verruciferum Chronozone in the Mediterranean Tethys. A revision of contemporaneous simoceratins in the Americas is founded on a comparative analysis withrespect to the European species $P$. aesinense.

Key words: Ammonitina, Pseudovolanoceras, Tithonian, Upper Jurassic, Mexico.

Ana Bertha Villaseñor [anab@servidor.unam.mx] and Celestina González-Arreola [arreola@ servidor.unam.mx], Departamento de Paleontología, Instituto de Geología, UNAM. C. P. 04510, México, DF Mexico; Federico Olóriz [foloriz@ugr.es], Departamento de Estratigrafía y Paleontología, Facultad de Ciencias, Universidad de Granada, Campus Universitario de Fuente Nueva, 18002, Granada, Spain.

This is an open-access article distributed under the terms of the Creative Commons Attribution License (for details please see creativecommons.org), which permits unrestricted use, distribution, and reproduction in any medium, provided the original author and source are credited. 
FoF Full text $(925.2 \mathrm{kB})$ 